\title{
LONG-TERM ANALYSIS OF RIVER TISZA WATER LEVEL DATA WITH REGARD TO THE ECOLOGICAL WATER DE- MAND OF FLOODPLAIN WATER BODIES
}

\author{
GYÖRGY DÉVAI ${ }^{1}$, MARTINA GYÖNGY ${ }^{1}$, CSABA BERTA $^{1}$, \\ FERENC BOGÁR ${ }^{2}$, IMRE BOGÁR ${ }^{2}$, GYÖRGY VARGA JR. ${ }^{2}$, \\ ZOLTÁN LUCZA ${ }^{2}$, LÁSZLÓ JÓZSEF SZABÓ ${ }^{1}$, IMRE SOMLYAI ${ }^{1}$, \\ SÁNDOR ALEX NAGY ${ }^{1}$, ISTVÁN GRIGORSZKY ${ }^{1 *}$
}

Received 25 March 2021, accepted in revised form 22 April 2021

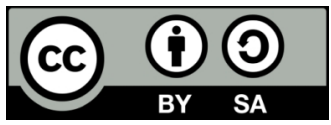

${ }^{1}$ Department of Hydrobiology, University of Debrecen, Debrecen

${ }^{2}$ Water Authority of Upper-Tisza-Region, Nyíregyháza

*Email: grigorszky.istvan@science.unideb.hu

\begin{abstract}
One of the main threats of our time is the increasing water demand not only globally, but also locally. These are often met at the expense of ecological water demand, jeopardizing the structural and operational conditions necessary to maintain good ecological status in aquatic and wetland habitats. This is why it is of great importance to explore possible water retention options. In 2019, based on the long-term data series on the water level of River Tisza, we studied the frequency and extent of flooding in the floodplain between Tiszabercel and Gávavencsello,, where there are valuable wetlands, including a 'sanctuary'type backwater. This was necessary because recently the floodplains have undergone negative changes. Their water volume has gradually decreased, their valuable wildlife has become rarer, some of them have completely dried out in the autumn and even one of them has burned out. From the analysis of the examined 48-years data, it could be concluded that flooding was relatively frequent in the sampled area, but the extent of water coverage had no significant effect either in space or time. It was also found that only water levels above $700 \mathrm{~cm}$ (based on the water meter of Tiszabercel, $98.36 \mathrm{mBf}$ ) could adequately ensure that the water bodies are filled up and flushed out. However, there is little chance of this, because of four reasons: (1) water levels of this height are becoming rare; (2) the duration and height of high water levels are mostly short in time; (3) water levels of several water bodies are artificially decreased; (4) the drainage effect of the River Tisza - which has been significantly incised after the river regulation - prevails in the area. Due to all, in the future, there would be a great need to maintain the water levels in the floodplain wetlands as efficiently as possible after the floods - for which we have made specific proposals for the places and methods to preserve the ecologically necessary amount of water.
\end{abstract}

Keywords: water demands, ecological status, River Tisza, floodplain, wetlands, degradation, flood, water level fluctuation, water retention

\section{Introduction}

A major challenge of our century is the extraordinary increase in water demand at local level, which is typical through the entire Earth. We are increasingly confronted with the fact that water needs exceed locally available water resources, both in terms of quantity and quality. There are primarily socio-economic reasons for this since before human civilization began, only the natural 
systems themselves had water needs. In the case of these, any changes were easily resolved, as due to the extreme diversity of the living world - there were always communities living in a given area and time - for which the usable water supply was adequate in terms of quality and quantity. For example, if a water supply has changed in quantitative terms - either positively or negatively -, that a given community was no longer able to tolerate it, the community was replaced by another one for which the 'new water supply' was appropriate for its entire life cycle. Humanity has changed this situation and is trying to change it continuously - sometimes intentionally, sometimes unintentionally -to satisfy the personal needs and the special socio-economic life forms. It has become clear nowadays that water resources in most of the Earth are not enough for adequate quality and quantity, not only to meet socio-economic needs but also to ensure the basic existence of humanity as a biological being. These extremely intense and rapid socio-economic changes have not only resulted in changes in water demand but also had an impact on the local and global climate. Before the establishment of human civilization, the ever-changing spatial and temporal changes in water resources did not have irreversible consequences for the living world and certain species. This was because there was enough living space, as well as free and well-maintained migratory routes, which were possibly available to occupy and populate the new habitats and thus for the survival of the species. However, humanity has made and continues to make significant transformations on our Earth, so these habitats are shrinking, ecological corridors and refugees are disappearing.

Based on all this, we can state that currently the local and global climate change and the increasing socio-economic demands on water resources are being superimposed. Accelerating the process that characterizes the Earth, if a community or assemblage is unable to tolerate the quantitative and qualitative changes of water resources, it will disappear from that habitat and be replaced by another. There is very little opportunity for an organism that disappears from a given habitat to reach refugees through ecological corridors. Unfortunately, it is difficult to accept the fact that if we have done something wrong, it can no longer be corrected, even though this is already the case on Earth. We know the fact that human needs have been far from in line with water resources in recent centuries. Mankind has lived with almost no care with the unchanging needs of natural systems for a long time - almost centuries. Therefore, in the current era, it is very important to know exactly the water resources in a given time interval and what it allows for us, both qualitatively and quantitatively!

In the spirit of these thoughts, we started to study the water management conditions of the floodplain between the settlements of Tiszabercel and Gávavencsellő along the upper section of the Tisza River in Hungary. Due to the aforementioned reasons, we studied the impact of floods in the Tisza floodplain, especially on the water bodies located there, the condition of which has deteriorated to an alarming extent in recent decades, both in terms of quantity and quality.

\section{Materials and methods}

According to the ecological landscape typology (Dévai et al., 1999), the floodplains belonging to the administrative area of the settlements of Tiszabercel and Gávavencsellő on both banks of the River Tisza are located on the Bodrogközi-Tisza-floodplain. Its surface area is between 94 and 102 meters (according to the Baltic Sea level), the majority of which is between 96 and 98 meters. Its length - following the line if the River Tisza (according to the river kilometre) - is $10 \mathrm{~km}$, its maximum width - measured perpendicular to the mainline of the River Tisza - is 2250 meters, its minimum width is 825 meters, its average width is 1350 meters and its area is $15 \mathrm{~km}^{2}$. During our investigation here in 1986, we recognized that 
the area is particularly valuable, but also very sensitive and vulnerable. At our suggestion, a significant part of the floodplain was declared protected in 1990, as an extension of the previously established Tiszatelek-Tiszabercel floodplain Nature Protection Area (Dévai and Miskolczi, 1997).

The first usable map of the area was made between 1782 and 1785 in the framework of a pioneering mapping called the First Military Survey (Pók, 1996). At that time, the right bank of the meandering River Tisza was still largely accompanied by extensive forests and the left bank was dominated by a vast marshland, from which only a few smaller forests stood out. According to the descriptions attached to the map, the banks of the River Tisza were shallow, with a width of 180-200 steps, depth at low water level $6-8$, at medium 12 while at high water level 16-19 [which is from the contemporary units used in Hungary (cf. Fodor, 1990), converted from step (0.7448 m) and Viennese step $(1.89648 \mathrm{~m})$ correspond to a bed width of 130-150 meters and a bed depth of 11-15.23 and 30-34 meters]. At the time of the II. Military Survey in 1861, the area still showed a similar picture but also shows the first flood defense embankment built in the area earlier (on the same route between Oláhzug and Marót-zug in the floodplain, an old embankment can also be found nowadays). The decisive change in the area took place in the 1860s, as a result of the river regulation, stated in the III. Military Survey maps (1884).

Before the river regulation in the second half of the 19th century, in the River Tisza floodplain on both sides of the Tiszabercel and Gávavencsellő administrative areas, the river had three large, two medium and one small meander. In total, it had a large double meander system of which the three largest meanders and both members of the double meander system were already considered

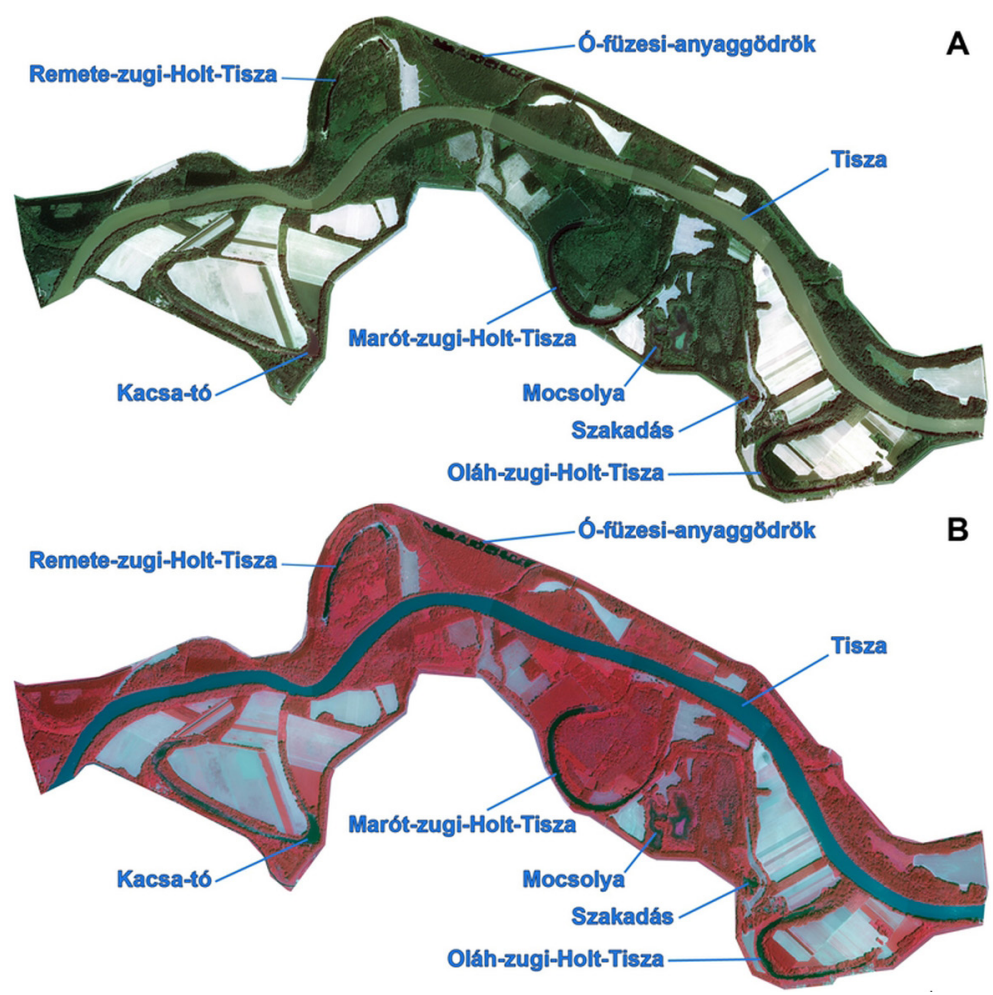

Fig. 1. Real (RGB, 1.A.) and false (NIR, 1.B.) colour composite image (@ Envirosense Hungary Kft.) of the sampled area, the River Tisza floodplain on both sides between the settlements of Tiszabercel and Gávavencsellő, with the indication of the studied water bodies 
overdeveloped (Dévai and Müller, 1998). During the river regulation - between 1862 and 1864 - the latter ones were cut off and as a result, these meanders became backwaters (Oláh-zugi-Holt-Tisza, Marót-zugi-HoltTisza, Remete-zugi-Holt-Tisza, Kacsa-tó) (Figure 1A and 1B.). The creation of the three additional water bodies shown in the figure can be caused by the great flood of 1970 . One (Szakadás) was caused by an embankment rupture. The other (Ó-füzesi-anyaggödrök) consists of a chain of material pits left after the construction of a new embankment section. The third (Mocsolya) is the herald of the former great marshland. However, during the river regulations of the 19 th century, it was placed on the protected side, drained and used for a long time as arable land. Due to the embankment corrections following the 1970s flood, it became part of the floodplain again and soon became a marsh again.

As a result of the river regulation, the length of the section of River Tisza between Tiszabercel and Gávavencsellő decreased significantly. The same difference in relative height is bridged by the river over a much shorter section, increasing the fall and ability of work of it. Before the river regulation in terms of sediment transport - the river was of equilibrium, considered as a midstage river. After the regulation, due to its increased working ability, it becomes able to remove more sediment, thus intensifying the linear erosion. The incision has begun, as a result of which the average water level of the river today is at least 3-4 meters lower than the level of the floodplain. This section of the River Tisza has been characterized by higher water level since 1954, as the damming effect of the Tiszalök-dam - its effect extends to the border of Dombrád.

The area of forests and marshes that previously dominated the floodplain has decreased significantly since the last quarter of the last century, with an increasing area occupied by pastures, meadows and then arable lands. This trend intensified until the middle of this century, so much so, that the aerial photographs and maps made at that time showed the only larger and coherent forest - but showing unmistakable signs of cultivation - in the Marót-zug.

Intensive agricultural and forestry activities are taking place in the current floodplain. Areas of relatively large size are covered by arable land, where mainly maize and sunflower are grown. Forests are regularly cut off and re-forested according to schedule and grasslands are constantly grazed and mowed. The main form of exploitation of backwaters is fishing, with the more and more intensive annual fish installation. The rapid increase in the number of anglers, the increase in activities related to the construction of fishing lodges (coastal plant extermination, pier construction, overfeed-in), as well as the introduction of alien species fundamentally change the habit of water bodies, not only their water and sediment quality status but also significantly reduces their biodiversity. In some water bodies (e.g. Oláh-zugi-Holt-Tisza), the anglers usually incorrect and sometimes uses ruthlessly rough methods, which causes significant destruction and serious damage in the habitats. Unfortunately, degradation due to unregulated tourist traffic and illegal dumping is becoming more widespread throughout the area.

Unfortunately, degradation-free areas are no longer located in this floodplain section and the share of less degraded areas are also very small. The Remete-zug, the Marót-zug, the Mocsolya and the Tód-alja - together with the water bodies belonging to them can be considered as sanctuary-type and in the future, they require strict protection and treatment in the interests of nature conservation (e.g. their valuable algal flora has been already brought to the attention by Kiss and Ács (2002) in the early 2000s).

The conditions of the floodplain can be quite different even in such a relatively small sample area, so this heterogeneity had to be mapped to take its effects into account in further studies. For the comparability with the actual terrain heights, we give the 
28.03.1970.-08.04.1970., Maximum water level: $706 \mathrm{~cm}$

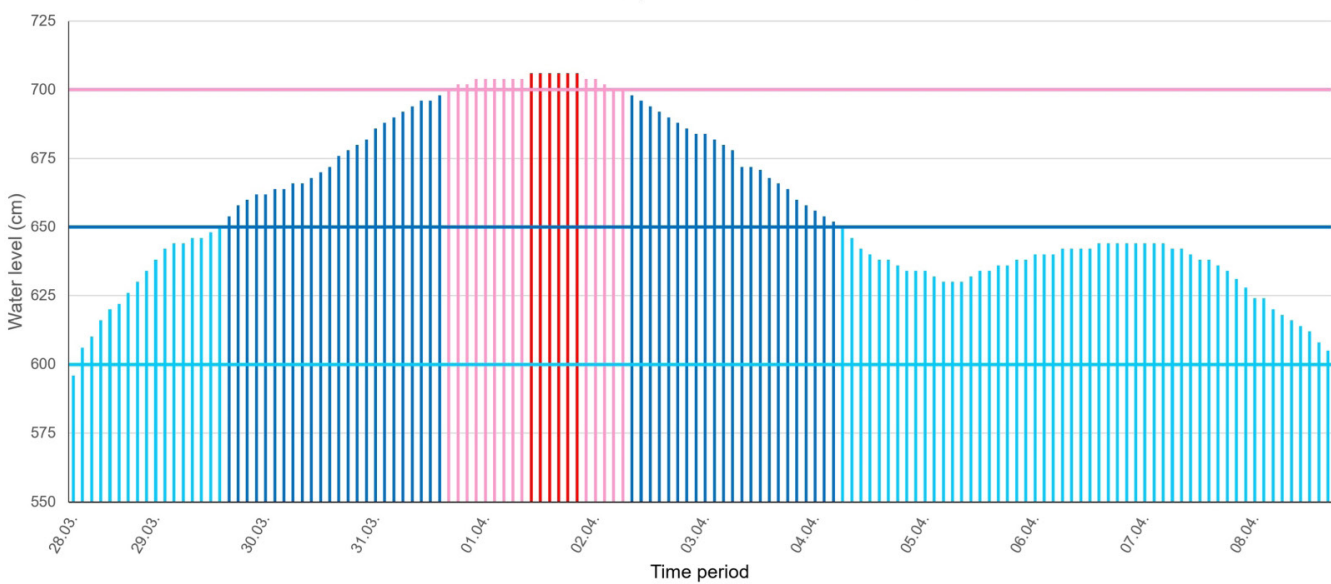

13.05.1970.-31.05.1970., Maximum water level: $826 \mathrm{~cm}$

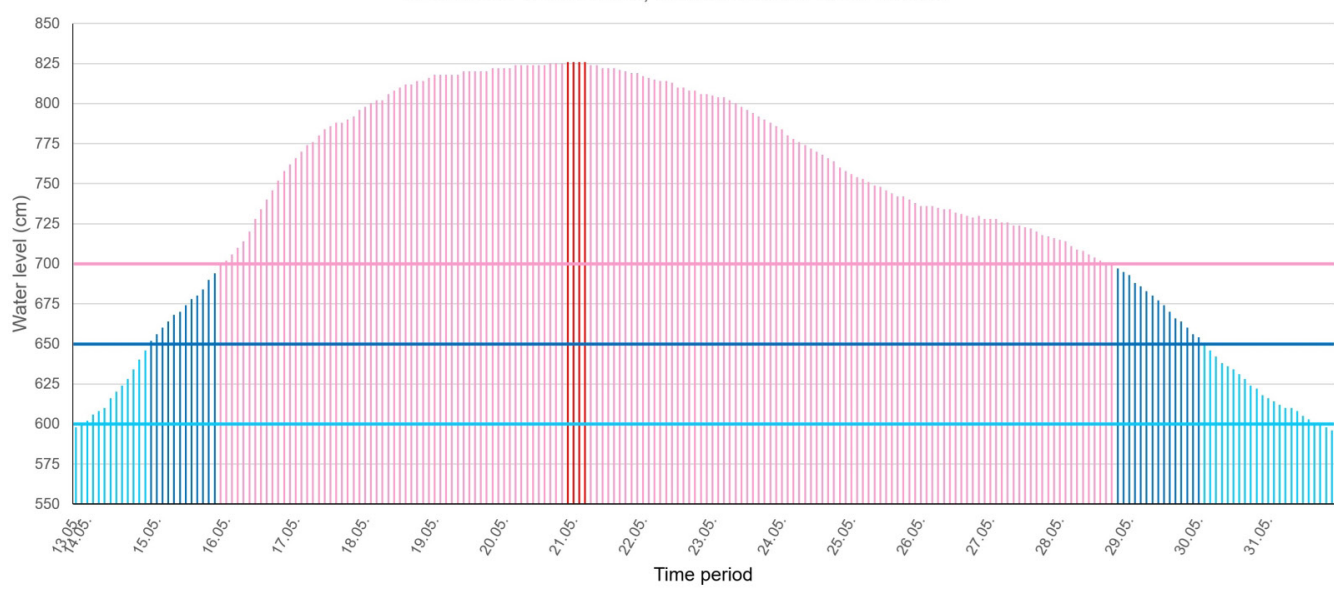

12.06.1970.-20.06.1970., Maximum water level: $762 \mathrm{~cm}$

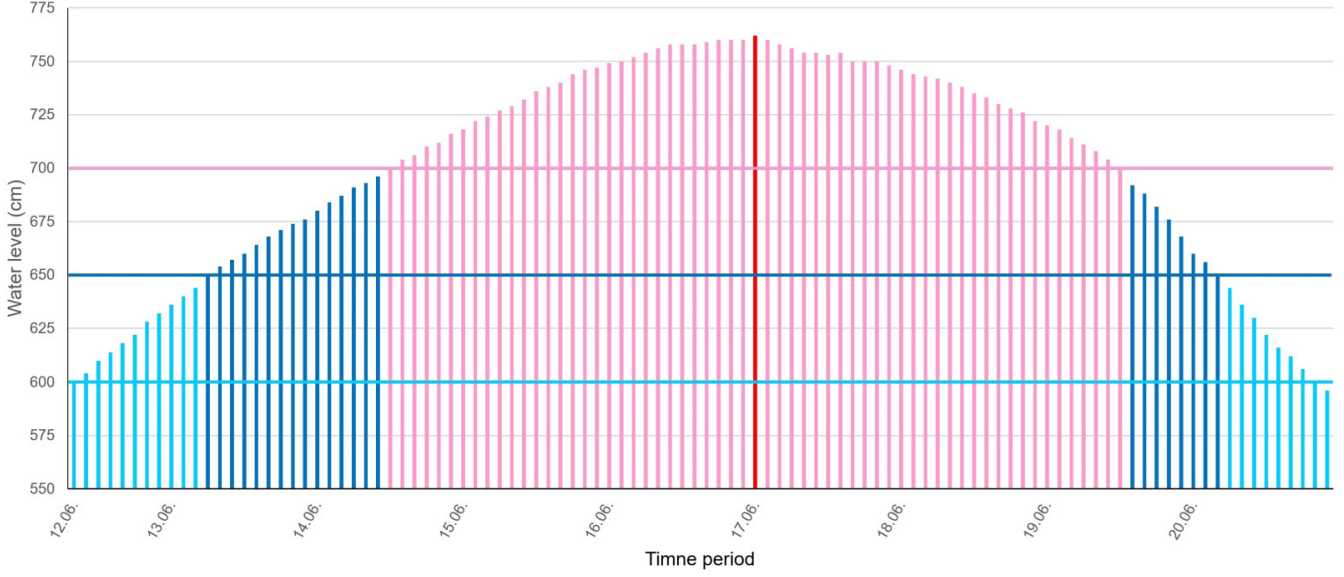

Fig. 2. Illustration of the evaluation of water level values at the Tiszabercel water meter exceeding the $600 \mathrm{~cm}$ water level in three periods of 1970 
height corresponding to the " 0 " point of the Tiszabercel water meter, referring to the meters above Baltic Sea level, which is $\mathbf{9 1 . 3 6}$ mBf.

According to the experience of local experts, the following main flood levels can be identified in the sampled area. Kacsa-tó receives water at a water level of $450 \mathrm{~cm}$ in Tiszabercel (95.86 mBf), but this water level does not cause a fundamental change in the floodplain. In the case of Marót-zug, receives water at a water level of $650 \mathrm{~cm}$ (97.86 mBf), but this also affects a relatively small part of the sample area. On two sections (Törökjáró and Kórós-tói-járó), flooding occurs only above a water level of $700 \mathrm{~cm}(98.36$ $\mathrm{mBf}$ ) which means that the entire area gets underwater only a water level above this.

Based on all this, we collected values from the Tiszabercel water meter data which values are above $600 \mathrm{~cm}$ ( $97.36 \mathrm{mBf})$, broken down daily and every two hours from 1969 to 2019. The 1969 start date was chosen to allow for a coordinated assessment of events over a longer period. The evaluation and processing of the work are presented by the example of the 1970's data (Figures 2.). For each year, we plotted water level values exceeding $600 \mathrm{~cm}$ in that year, which can be even more times in one year, for example, in 1970 such a situation occurred 3 times
(Figure 2.). In the tables, the values between 600 and $649 \mathrm{~cm}$ are marked with light blue, those which are between 650 and $700 \mathrm{~cm}$ are marked with dark blue, those which starting from $700 \mathrm{~cm}$ are marked with pink and peaks with red. The same colouring is applied to the graphs showing values above $600 \mathrm{~cm}$.

For example with the analysis of the data from the first chart of 1970 shows that between March 28 and April 8, the water level exceeded $600 \mathrm{~cm}$ through 12 days. The curve is elongated and double-peaked, with the maximum water level at the first peak at $706 \mathrm{~cm}$. From this exemplary figure and data set presented as a table, it can be concluded that no significant and prolonged flooding occurred in the area at the early spring (the water level was above $700 \mathrm{~cm}$ for only around 38 hours).

\section{Results}

The height of the flood waves and its characteristics are of great importance in many respects. Flood waves fundamentally determine the structural and operational characteristics of the entire ecosystem of a floodplain in a given year, even larger and mainly long-lasting flood waves can affect in several years.

Table 1. The duration of flood waves reaching and exceeding $600 \mathrm{~cm}$ of the Tiszabercel water meter, distribution of the daily water level ranges and the peak values of the maximum water levels of the given flood waves (based on data provided by FETIVIZIG)

\begin{tabular}{|c|c|c|c|c|c|}
\hline Flood period & $<600 \mathrm{~cm}$ & $600-649$ & $650-699$ & $>700 \mathrm{~cm}$ & Maximum \\
\hline 28. 03. 1970. - 08. 04. 1970. & \multirow{3}{*}{326} & 7 & 4 & 1 & 706 \\
\hline 13. 05.1970. - 31.05. 1970. & & 3 & 2 & 13 & 826 \\
\hline 12. 06. 1970. - 20.06. 1970. & & 2 & 1 & 6 & 726 \\
\hline 02. 01. 1971. - 05. 01. 1971. & 360 & 5 & 0 & 0 & 621 \\
\hline
\end{tabular}




\begin{tabular}{|c|c|c|c|c|c|}
\hline Flood period & $<600 \mathrm{~cm}$ & $600-649$ & $650-699$ & $>700 \mathrm{~cm}$ & Maximum \\
\hline \multirow[b]{2}{*}{ 31.12.1973. - 01. 01. 1974.} & 364 & \multirow[b]{2}{*}{1} & \multirow[b]{2}{*}{1} & \multirow[b]{2}{*}{0} & \multirow[b]{2}{*}{682} \\
\hline & \multirow{6}{*}{331} & & & & \\
\hline 13.06.1974. - 28. 06. 1974. & & 2 & 2 & 6 & 766,603 \\
\hline 02.07.1974. - 07. 07. 1974. & & 2 & 3 & 0 & 667 \\
\hline 24.07.1974. - 29.07.1974. & & 2 & 2 & 0 & 674 \\
\hline 24.10.1974. - 08.11. 1974. & & 12 & 2 & 0 & 647,654 \\
\hline 31. 12.1974. - 03.01. 1975. & & 2 & 0 & 0 & 629 \\
\hline 05. 04.1975. - 21.05. 1975. & 354 & 9 & 0 & 0 & 634,622 \\
\hline 03. 04.1976. - 14. 04. 1976. & 355 & 3 & 6 & 2 & 710 \\
\hline 14. 02.1977. - 03.03. 1977. & \multirow{2}{*}{347} & 6 & 7 & 1 & 670,700 \\
\hline 06.04.1977. - 09.04. 1977. & & 4 & 0 & 0 & 628 \\
\hline 03.03.1978. - 10.03. 1978. & \multirow{4}{*}{350} & 7 & 0 & 0 & 637,635 \\
\hline 05. 05. 1978. - 08. 05. 1978. & & 3 & 0 & 0 & 635 \\
\hline 26. 05. 1978. - 31. 05. 1978. & & 3 & 2 & 0 & 659 \\
\hline 31.12.1978. - 08. 01. 1979. & & 2 & 2 & 4 & 766 \\
\hline 27.01.1979. - 19.02. 1979. & \multirow[t]{3}{*}{328} & 5 & 3 & 12 & $843,821,620$ \\
\hline 30.03.1979. - 12.04.1979. & & 7 & 0 & 0 & 644,613 \\
\hline 14.12.1979. - 15. 12. 1979. & & 2 & 0 & 0 & 605 \\
\hline 06.04.1980. - 09. 04. 1980. & \multirow{5}{*}{334} & 3 & 0 & 0 & 602 \\
\hline 03. 06. 1980. - 06. 06. 1980. & & 3 & 0 & 0 & 628 \\
\hline 05. 07. 1980. - 11. 07. 1980. & & 3 & 3 & 0 & 656 \\
\hline 24.07. 1980. - 08. 08. 1980. & & 2 & 2 & 10 & 773 \\
\hline 08.11.1980. - 14.11. 1980. & & 4 & 2 & 0 & 656 \\
\hline 12.03.1981. - 31.03. 1981. & \multirow{3}{*}{339} & 6 & 3 & 9 & 760 \\
\hline 13.12.1981. - 19.12. 1981. & & 2 & 3 & 0 & 682 \\
\hline 26.12.1981. - 30.12. 1981. & & 3 & 0 & 0 & 632 \\
\hline 03.01.1982. - 10. 01. 1982. & 359 & 3 & 3 & 0 & 669 \\
\hline 06. 04.1983. - 08. 04. 1983. & \multirow{2}{*}{359} & 2 & 0 & 0 & 614 \\
\hline 04.05. 1983. - 08. 05. 1983. & & 4 & 0 & 0 & 642 \\
\hline 07.07.1984. - 11.07.1984. & 363 & 3 & 0 & 0 & 636 \\
\hline
\end{tabular}


Landscape \& Environment 15 (1) 2021. 16-32

\begin{tabular}{|c|c|c|c|c|c|}
\hline Flood period & $<600 \mathrm{~cm}$ & $600-649$ & $650-699$ & $>700 \mathrm{~cm}$ & Maximum \\
\hline 19. 03. 1985. - 29.03. 1985. & \multirow{3}{*}{343} & 6 & 3 & 0 & 660 \\
\hline 03. 05. 1985. - 13.05. 1985. & & 2 & 2 & 5 & 748 \\
\hline 21. 05. 1985. - 25. 05. 1985. & & 4 & 0 & 0 & 643 \\
\hline 01. 04. 1986. - 04. 04. 1986. & \multirow{2}{*}{355} & 3 & 0 & 0 & 616 \\
\hline 21. 04. 1986. - 27. 04. 1986. & & 2 & 5 & 0 & 689 \\
\hline 01. 04. 1987. - 06. 04. 1987. & 355 & 6 & 4 & 0 & 661,636 \\
\hline 25. 03. 1988. - 05. 04. 1988. & 350 & 13 & 3 & 0 & $\begin{array}{c}640,657,634, \\
651\end{array}$ \\
\hline 01. 03. 1989. - 03.03. 1989. & \multirow{3}{*}{350} & 3 & 0 & 0 & 622 \\
\hline 09. 05. 1989. - 15. 05. 1989. & & 3 & 4 & 0 & 685 \\
\hline 18. 12. 1989. - 23.12. 1989. & & 4 & 1 & 0 & 651 \\
\hline 22. 05. 1991. - 25.05. 1991. & 361 & 4 & 0 & 0 & 638 \\
\hline 06. 04. 1992. - 11.04. 1992. & \multirow{2}{*}{356} & 4 & 0 & 0 & 641 \\
\hline 01.11. 1992. - 07.11. 1992. & & 4 & 2 & 0 & 655 \\
\hline 22.12.1993. - 29.12. 1993. & 358 & 1 & 3 & 3 & 718 \\
\hline 21. 04. 1994. - 23.04. 1994. & 363 & 2 & 0 & 0 & 608 \\
\hline 01. 03. 1995. - 03.03. 1995. & \multirow{5}{*}{338} & 3 & 0 & 0 & 620 \\
\hline 30. 03. 1995. - 01.04. 1995. & & 2 & 0 & 0 & 616 \\
\hline 29. 04. 1995. - 05. 05. 1995. & & 2 & 5 & 0 & 677 \\
\hline 19.11. 1995. - 23.11. 1995. & & 3 & 0 & 0 & 647 \\
\hline 26.12.1995. - 07.01. 1996. & & 4 & 3 & 5 & 754 \\
\hline 14. 04. 1998. - 26. 04. 1998. & \multirow{4}{*}{314} & 8 & 3 & 0 & 652,651 \\
\hline 20.06. 1998. - 27.06. 1998. & & 2 & 5 & 0 & 688 \\
\hline 10. 07. 1998. - 23.07. 1998. & & 1 & 3 & 9 & 733 \\
\hline 31. 10. 1998. - 21.11. 1998. & & 4 & 4 & 12 & 839 \\
\hline 04. 03. 1999. - 22.03. 1999. & \multirow{2}{*}{339} & 3 & 4 & 11 & 831 \\
\hline 20. 04. 1999. - 28.04. 1999. & & 3 & 5 & 0 & 694 \\
\hline 12. 02. 2000. - 12.02. 2000. & \multirow{2}{*}{326} & 0 & 3 & 0 & 696 \\
\hline 11. 03. 2000. - 26.04. 2000. & & 5 & 12 & 20 & 700,882 \\
\hline 05. 03. 2001. - 31.03. 2001. & 339 & 6 & 6 & 14 & 828,725 \\
\hline 01. 02. 2002. - 03.02. 2002. & \multirow{3}{*}{347} & 3 & 0 & 0 & 697 \\
\hline 14. 02. 2002. - 19.02. 2002. & & 3 & 2 & 0 & 669 \\
\hline 02. 03. 2002. - 13.03. 2002. & & 2 & 7 & 1 & 700 \\
\hline 22.03. 2004. - 03.04. 2004. & \multirow{3}{*}{349} & 5 & 2 & 4 & 726 \\
\hline 13. 04. 2004. - 18.04. 2004. & & 4 & 0 & 0 & 645 \\
\hline 05. 12. 2004. - 08.12. 2004. & & 2 & 0 & 0 & 628 \\
\hline 20.03. 2005. -04.04. 2005. & \multirow{2}{*}{337} & 4 & 6 & 0 & 674,676 \\
\hline 22. 04. 2005. - 11.05. 2005. & & 9 & 6 & 3 & 718 \\
\hline
\end{tabular}




\begin{tabular}{|c|c|c|c|c|c|}
\hline Flood period & $<600 \mathrm{~cm}$ & $600-649$ & $650-699$ & $>700 \mathrm{~cm}$ & Maximum \\
\hline 25.03.2006. - 30.04. 2006. & \multirow{2}{*}{318} & 6 & 7 & 22 & 825 \\
\hline 30.05. 2006. - 12.06. 2006. & & 4 & 4 & 4 & 718 \\
\hline 11.02. 2007. - 20.02. 2007. & \multirow{2}{*}{353} & 2 & 5 & 1 & 701 \\
\hline 04.03.2007. - 09.03. 2007. & & 2 & 2 & 0 & 658 \\
\hline 04. 03. 2008. - 09. 03. 2008. & \multirow{3}{*}{350} & 4 & 0 & 0 & 630 \\
\hline 14.04. 2008. - 21.04. 2008. & & 4 & 2 & 0 & 654 \\
\hline 27.07. 2008. - 02.08. 2008. & & 1 & 3 & 2 & 723 \\
\hline 13. 03. 2013. - 20. 03. 2013. & \multirow{2}{*}{341} & 6 & 0 & 0 & 647 \\
\hline 02. 04. 2013. - 21. 04. 2013. & & 3 & 8 & 7 & 755 \\
\hline 26. 02. 2016. - 28. 02.2016.* & 365 & 1 & 0 & 0 & 609 \\
\hline 08. 02. 2017. - 13. 02. 2017. & \multirow{2}{*}{355} & 1 & 3 & 1 & 809 \\
\hline 17. 12. 2017. - 23. 12. 2017. & & 2 & 3 & 0 & 690 \\
\hline 24.05. 2019. - 30. 05. 2019. & 359 & 2 & 4 & 0 & 678 \\
\hline Altogether & 13190 & 304 & 197 & 188 & \\
\hline *Icy flood & & & & & \\
\hline
\end{tabular}

Based on the analysis of the data in Table 1., in the 51 years between 1969-2019, there were 3 years (2009 to 2011) for which no data were available. It has to be brought forward because - according to other sources - there was high water levelled year among them, and therefore our compilation cannot be considered complete for the 51 years.

In 10 years out of the 48 years we studied (1969, 1972, 1990, 1996, 1997, 2003, 2012, 2014,2015 , and 2018), no water level was observed that exceeded $600 \mathrm{~cm}$. In the remaining 38 years, there were 13 years when the flood occurred once, 12 years when the flood occurred twice, 7 years when the flood occurred three times, 3 years when the flood occurred four times, 2 years when a flood occurred five times and in 1 year when the flood occurred six times. This represents a total of 83 flood waves, of which 3 were cross-bordered years (1973-1974, 1974$1975,1978-1979)$. Of the 83 flood waves, 70 had 1 peak, 11 had 2 peaks and $1-1$ had 3 and 4 peaks.

It is very informative to compare the distribution of non-flooded and flooded days and days above different water levels. Of the 13,879 days in the period we studied, about 13,190 days did not have a water level higher than $600 \mathrm{~cm}$, which corresponds to $95 \%$. The share of days with a water level of $600 \mathrm{~cm}$ or more (689 days) is therefore very small (5\%). From these 689 days, 304 had a range of 600-649 cm, 197 days had a range of 650-699 $\mathrm{cm}$ and 188 days had a range of 700 - higher cm (percentages: $44-29-27 \%$ ). This distribution means that the number of days of real flooding over the entire 51-year period is extremely low, at just $1.35 \%$.

The total number of days when the maximum water level in the sampled area was $600 \mathrm{~cm}$ or more was 689 . The number of days below the maximum water level of $650 \mathrm{~cm}$ is the highest (304). The number of days below the maximum water level of 700 $\mathrm{cm}$ or more is the lowest (188). The number of days between the maximum water level of $650-699 \mathrm{~cm}$ is relatively low (197). The maximum peak height of the 83 flood waves (the biggest in the case of a continuous but double- or multi-peaked flood wave) were 27-27 times between 600 and $650 \mathrm{~cm}$, and $700 \mathrm{~cm}$ or higher, respectively. In 29 cases it was between 650 and $699 \mathrm{~cm}$.

The situation is very unfavourable for wetlands if we further analyse the peaks of 
floods at $700 \mathrm{~cm}$ or above. It turns out that 56 of the 83 flood waves do not peak in this zone only in lower heights, and relatively many (19) of the 27 peaks only appears less than 10 days and only less than half (8) belong to the category which peaks in this section for more than 10 days and the maximum number of days that can be included here is only 22 .

Among the water bodies of the floodplain, the Marót-zugi-Holt-Tisza is arguably the most valuable, so we also suggested including it into the 'sanctuary'-type backwaters. In recent years - in our experience - the amount of water has significantly decreased, till autumn there will be a short of $2 \mathrm{~m}$ at water level. Therefore, we tried to characterize the general condition of the water bodies based on the water yield characteristics of the backwater.

Figure 3. shows a cross-section of the floodplain through the River Tisza and the Marót-zugi-Holt-Tisza, as one of the sampled areas. The well-studied flood levels convincingly show that the complete flooding of the Marót-zugi-Holt-Tisza can only be expected at flood waves exceeding $700 \mathrm{~cm}$. Based on the median values of the last half-century, it can be concluded that the maximum of the average values is quite far from the actual flood levels that causing flooding. The minimum of the average values is under the bottom level of the backwater (Fig. 4.).

It is very informative to highlight two different water yielded years and examine them in a little more detail in the case of Marótzugi-Holt-Tisza (Fig. 5-8.). In 2018, water level exceeding $600 \mathrm{~cm}$ did not occur, so the backwater left without water replenishment. In 2019, water level exceeding $600 \mathrm{~cm}$ for only 6 days, and the peak was relatively low $(678 \mathrm{~cm})$ (Table 1.). Thus, this also resulted in only a partial water replenishment, mainly from the lower areas of the Marót-zugi-HoltTisza and through the Mocsolya (through a ditch for drainage and a canal connecting the Mocsolya with the Marót-zugi-Holt-Tisza). The annual average values (Figures 5. and 7.) and the annual daily extreme values (Fig. 6. and 8.), the average water level was close to the bottom level of the backwater in both years or coincided with that, and the minimum water level proved to be below the bottom level.

Looking at these conditions, we also considered it necessary to examine the water yield of the River Tisza. We analysed in detail the changes in the water level of the river over time based on the 50-year (1969-2018) data series of the Tiszabercel water meter. The nature of the water level change was determined from the mean values by linear regression analysis using the OLS method (since the seasonal data have no error). The trend in the changes of the average values has a decreasing tendency, but in the examined period the correlation is only marginally significant (Fig. 9.). Taking into account the climate change scenarios for the River TiszaGreat Plain, it is highly probable that due to

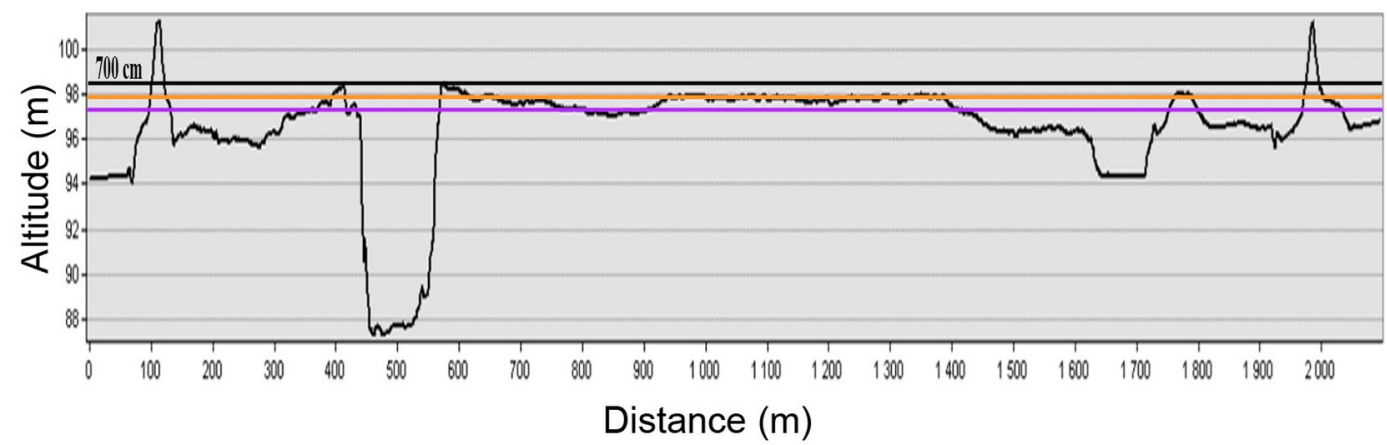

Fig. 3. A cross-section of the sample area that passes through the Marót-zugi floodplain, with indication the category boundaries of the flood waves analysis (purple: $600 \mathrm{~cm}$; orange: $650 \mathrm{~cm}$ and black: 700 $\mathrm{cm}$ ) (based on data provided by FETIVIZIG, modified version) 


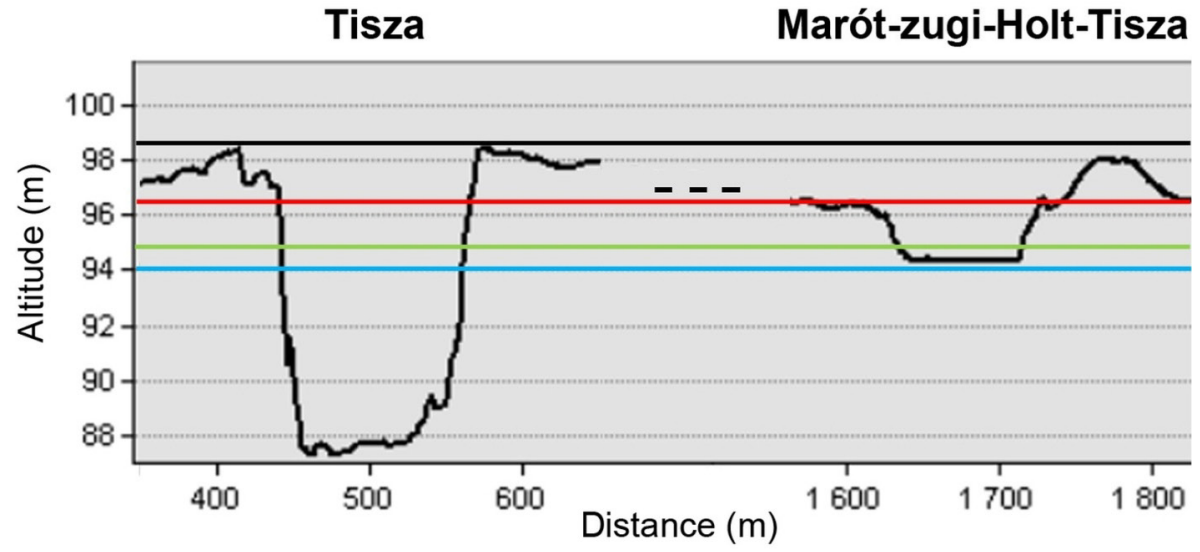

Fig. 4. Virtual saturation of the River Tisza and Marót-zugi-Holt-Tisza, based on the 48-year average values of the characteristic water levels (blue: minimum; green: medium; red: maximum and black: 700 $\mathrm{cm}$ ) (based on data provided by FETIVIZIG, modified version)

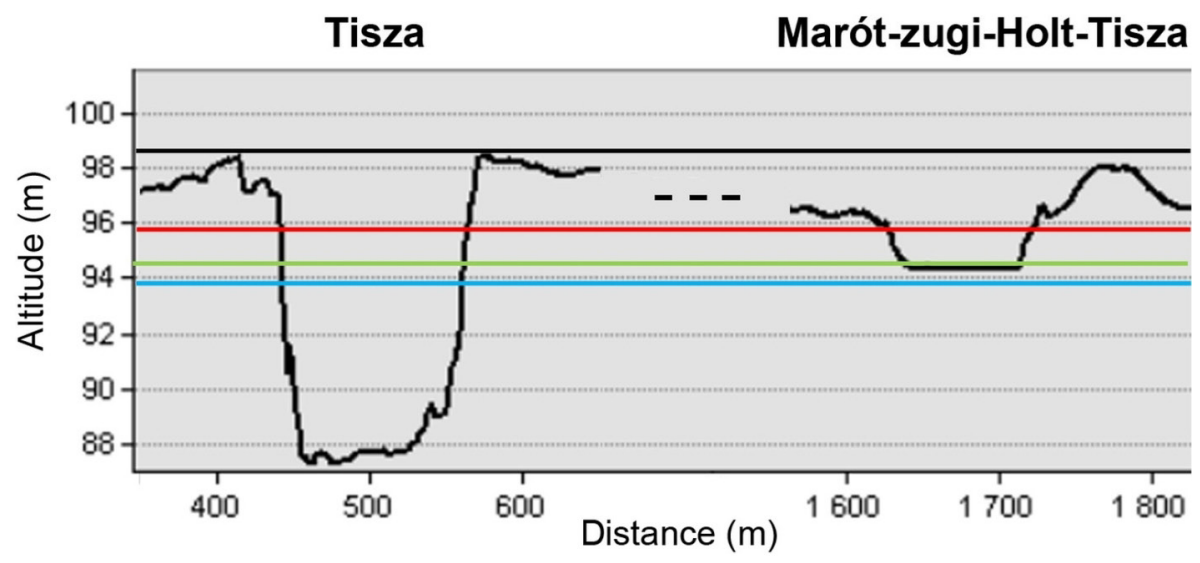

Fig. 5. Virtual saturation of the River Tisza and Marót-zugi-Holt-Tisza, according to the average values of the water levels typical in 2018 (blue: minimum; green: medium; red: maximum and black: $700 \mathrm{~cm}$ )

(based on data provided by FETIVIZIG, modified version)

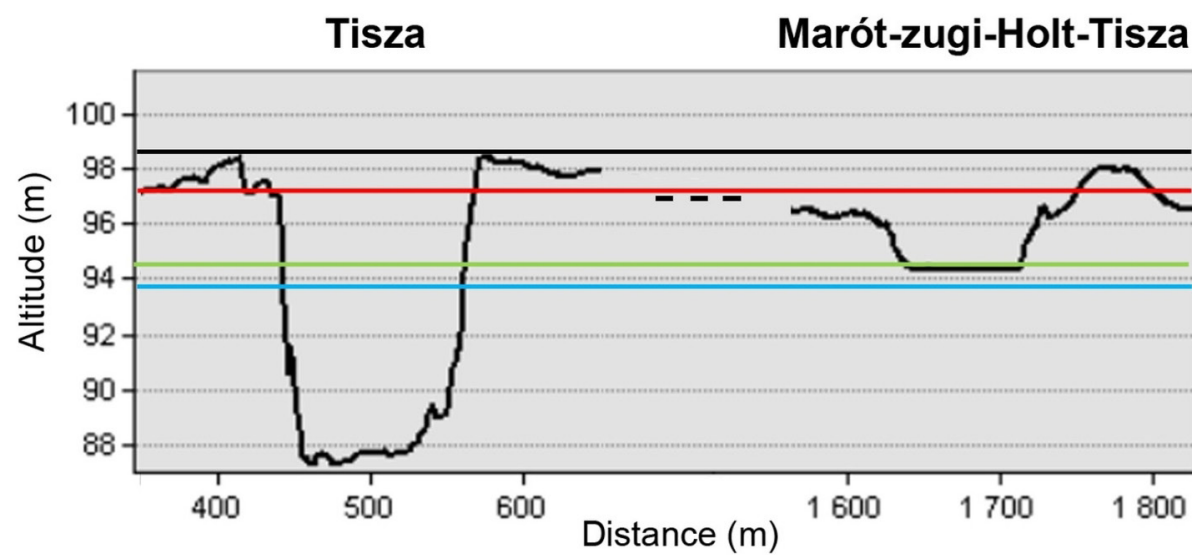

Fig. 6. Virtual saturation of the River Tisza and Marót-zugi-Holt-Tisza, according to the daily extreme water level values observed in 2018 (blue: minimum; green: medium; red: maximum and black: 700 $\mathrm{cm}$ ) (based on data provided by FETIVIZIG, modified version) 


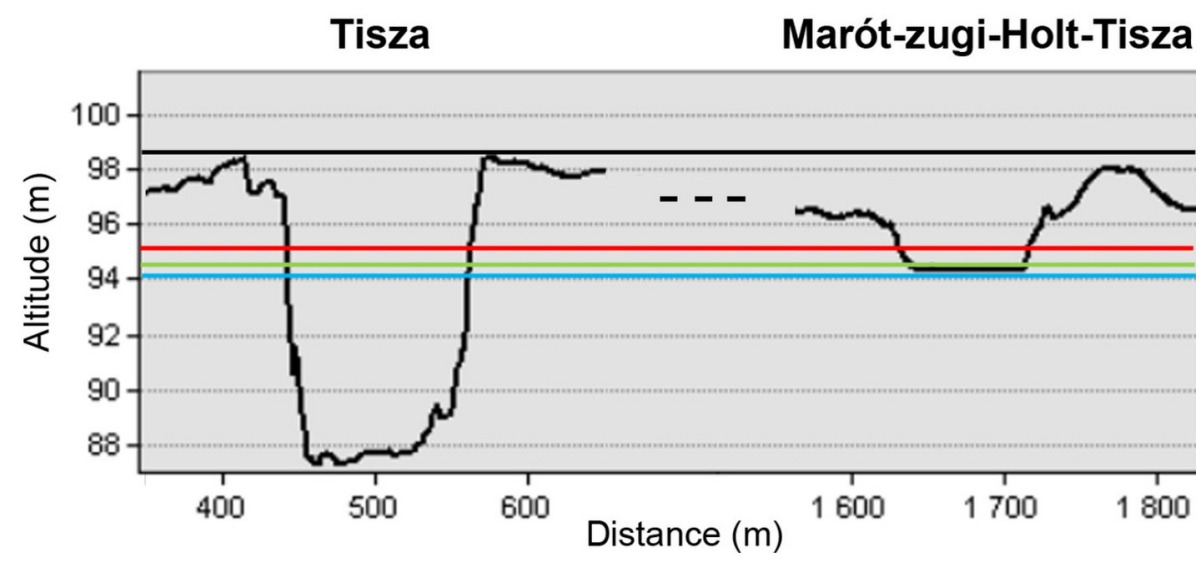

Fig. 7. Virtual saturation of the River Tisza and Marót-zugi-Holt-Tisza, according to the average values of the water levels typical in 2019 (blue: minimum; green: medium; red: maximum and black: $700 \mathrm{~cm}$ ) (based on data provided by FETIVIZIG, modified version)

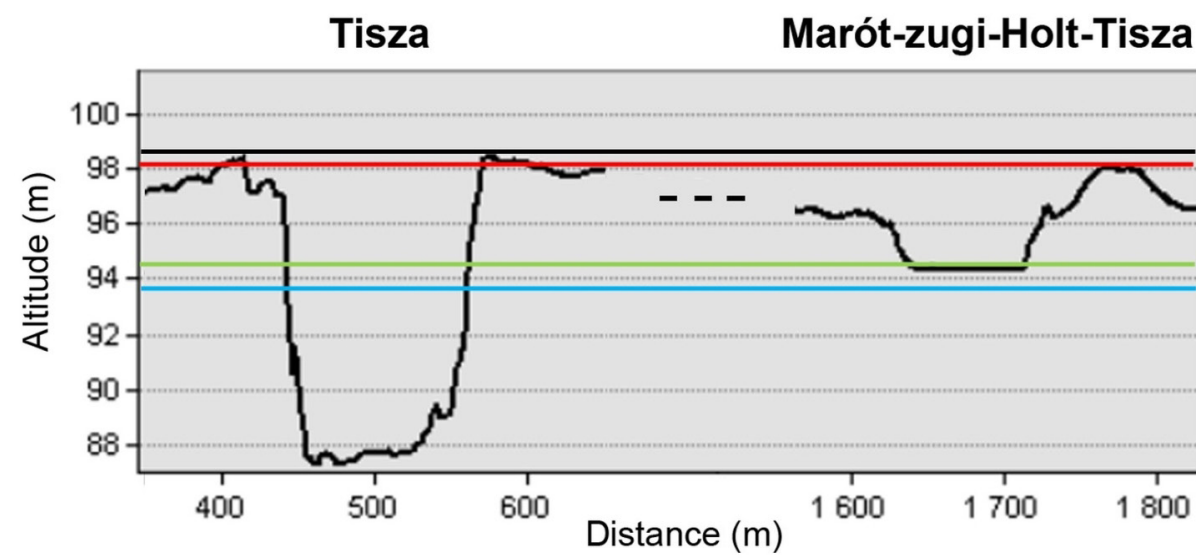

Fig. 8. Virtual saturation of the River Tisza and Marót-zugi-Holt-Tisza, according to the daily extreme water level values observed in 2019 (blue: minimum; green: medium; red: maximum and black: 700 $\mathrm{cm}$ ) (based on data provided by FETIVIZIG, modified version)

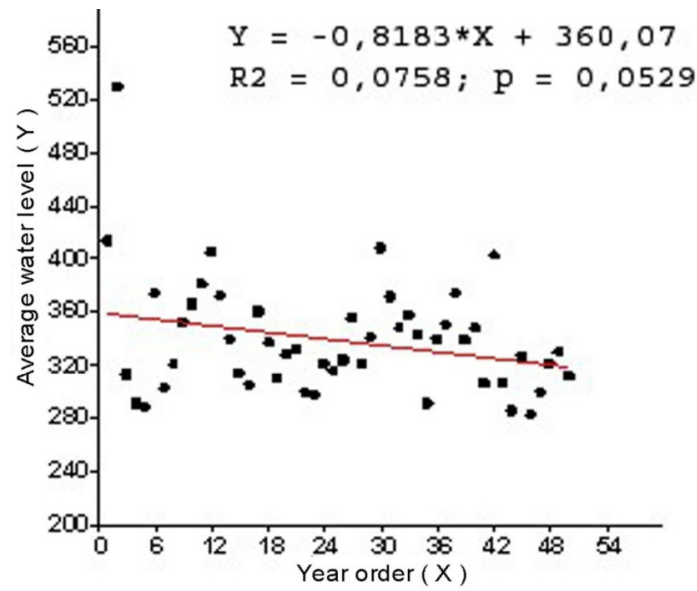

Fig. 9. Changes in the water level of the River Tisza based on the annual averages of the period 19692019, using the data series of the Tiszabercel water meter (based on data provided by FETIVIZIG, modified version) 
the increasing water demand, this decreasing trend will continue even in this section of the river, presumably to a greater extent than before.

Similar results are reported by Bokodi (2017), who detected a significant decrease in water level at Vásárosnamény, based on the average values of a 140-year time series. These processes are much larger in scope and broader, as in the case for the Danube (Hein et al., 2018).

\section{Discussion}

Based on the analysis of the former data series, it is not surprising that the condition of floodplain water bodies has deteriorated significantly in recent decades. It would be particularly important to preserve our valuable habitats and their wildlife, where possible, restore the degraded habitats into their near-natural state. In our opinion, the wetlands of this sample area have not yet been irreversibly damaged, so we tried to explore the main causes of degradation to make a well-founded proposal for rehabilitation.

The main reason for the deterioration is the significant decrease in the amount of water needed to meet the ecological water demand of water bodies, and often even its complete absence. The decrease in water volume can be traced back to both natural and artificial causes. In our view, two of the natural causes play a serious role.

One is evapotranspiration, which means the evaporation of the water surface and the evaporation of vegetation together. Although water loss caused by evapotranspiration is important, it should be classified in the category that should be accepted, that is, that can hardly be changed (evaporation) and should not be changed (transpiration). The peculiarities of these water bodies are why the value of evapotranspiration is high. Due to the large surface area concerning the depth and the richness of the macro-vegetation, at the same time ensure the uniqueness and diversity of these water bodies.
The other natural cause is leakage. Although the extent of this is not very high due to the moderate water permeability of the soils. It should be taken into account, especially since a watertight layer has not yet been formed in the bed of relatively young water bodies. Besides, even in this dammed section, the water level of River Tisza continues to fall (Figure 9.), as a result of which the River Tisza may be able to 'suck down' some of the remaining water from the water bodies, especially in late summer and early autumn. Clarification of these conditions would also be important, which would require the analysis of data sets of groundwater wells that have not yet been established at all in the floodplain. Nevertheless, it can be stated that there is not much chance to change the leakage either.

The reduction of water volume cannot be substantially prevented from natural causes, therefore the role of artificial solutions is appreciated. The most important is the abandonment of the drainage practice and the solution of the necessary water replenishment, as well as the coordination of these two. Ensuring a water level appropriate to the character of a given water body is not only important in quantitative terms. Ecological water demand also has a quality side, which is also important, and even equivalent to quantity, if we want to satisfy the appropriate structural and operational conditions of the ecological system (Ács et al., 2020).

Taking into account the current terrain conditions, it can be stated that, similarly to the Kacs-tó, there is no favourable external water replenishment opportunity in the other water bodies too. Moreover, in some cases, drainage ditches ensure that the amount of water entering during major floods is drained as soon as possible. Because of this, the water that may remain inside the water bodies after the floods does not prove to be longlasting. By the spring of 2019, for example, the Oláh-zugi-Holt-Tisza and the Szakadás were completely dried out (Fig. 10-11.), the vegetation in the riverbed was getting on fire 
and even the shoreline was scorched. There was hardly any water in the Mocsolya, and the water level in the Marót-zugi-Holt-Tisza was at least $1.5 \mathrm{~m}$ lower than before (Fig. 12.), which is also confirmed by the dried-out channel connecting the Mocsolya (Fig. 13.).

These events and processes result in a large-scale loss of biodiversity and natural value. We, therefore, consider it essential to reduce their impact as much as possible and, to eliminate it, if possible, in the end. For this, we make the following suggestions.

As an integral part of the river basin management program, the water sector should be able to retain water in floodplains following flooding. For this purpose, we would consider a flood gate solution suitable for regulating the water level, also ensuring the conditions for the rapid lowering of the water level (e.g. before a major flood wave). As this program can certainly only be implemented with costly investments, in the case of non-priority water bodies, a bottom sill with a damper may be considered as an ancillary solution to allow at least some water retention. Due to the expected effects of climate change, these interventions should be considered in as many floodplain backwaters and other wetlands as possible (such as the Mocsolya in the sample area, which is a swamp in terms of ecological water body type), but at least in really valuable water bodies. The conditions of the MarótZugi-Holt-Tisza and the Mocsolya, clearly justifying the investment, so we recommend the solution of water level regulation and the monitoring of the changes to be implemented as soon as possible.

In our opinion, the floodplain, as a large riverbed, has a dual function. In particular, it must be able to play its full role in flood protection, i.e. the smooth drainage of water, ice and sediment. Secondly, it must be able to satisfy the habitat conditions as fully as possible, i.e. to ensure the most optimal living conditions of the microbiota, flora and fauna native to the territory. Our surveys in the sample area clearly show that, from an ecological point of view, the flood plain, like the hydrological and hydrographic disciplines, cannot be treated uniformly. It is, therefore, necessary to separate the floodplain sections that can be considered relatively ecologically uniform. Then to assess the possibilities of accelerating the flow of flood waves and ways to reduce the roughness in the given

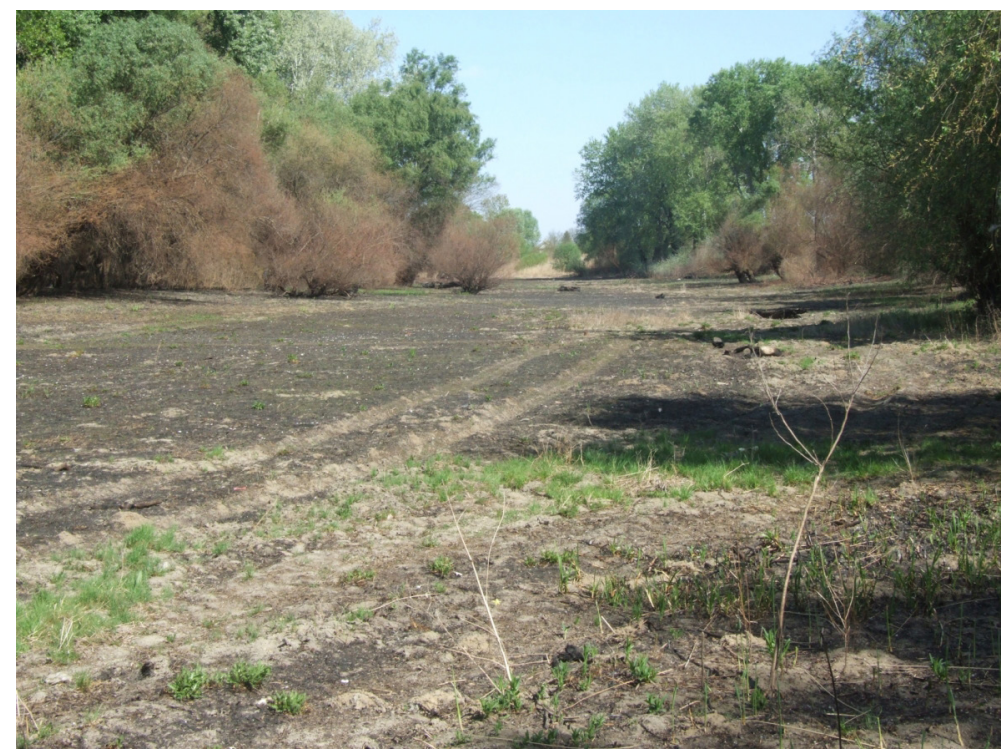

Fig. 10. The river bed of the dried out and scorched Oláh-zugi-Holt-Tisza in the spring of 2019 (Photo: György Dévai, April 20, 2019) 


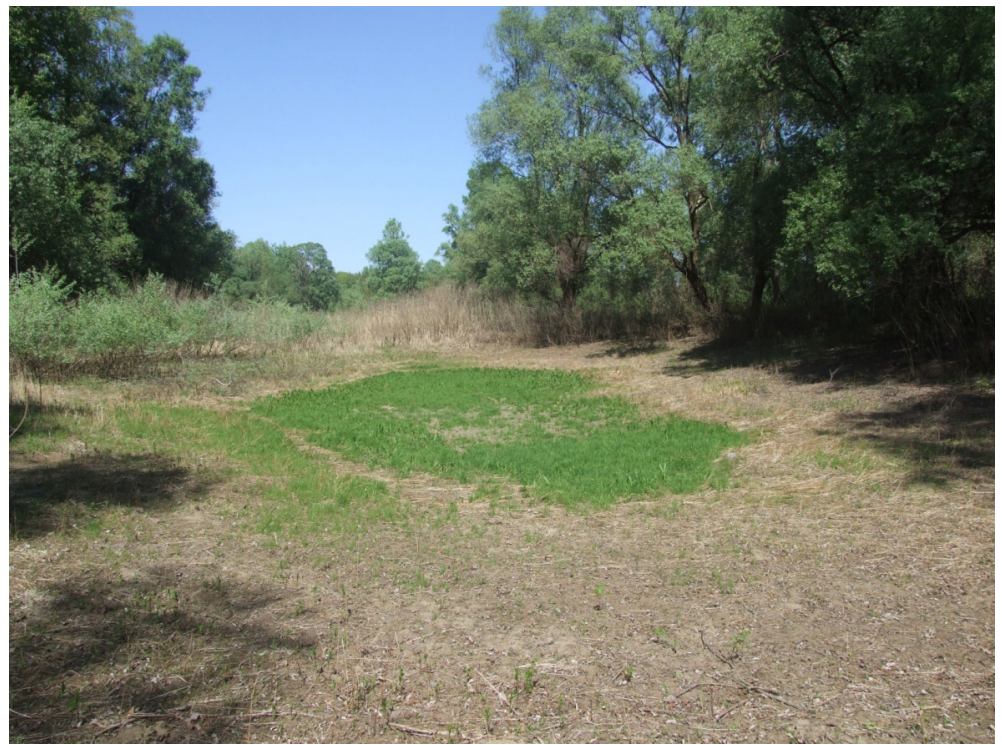

Fig. 11. Dried out river bed of the Szakadás in the spring of 2019 (Photo: György Dévai, April 20, 2019)

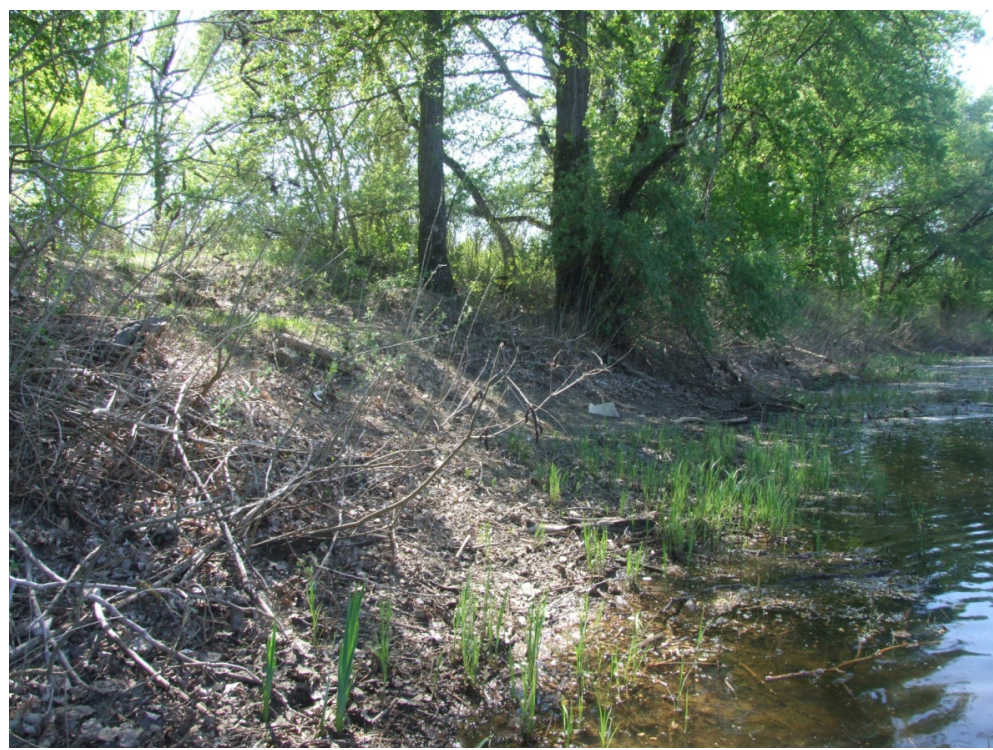

Fig. 12. The huge amount of water missing from the Marót-zugi-Holt-Tisza can be seen in the spring of 2019 (Photo: György Dévai, April 20, 2019)

section, and then proposing the necessary and possible intervention methods. We consider it necessary to develop a longterm, integrated, i.e. clearly prioritized flood and nature protection concept for each floodplain section, based on a comprehensive assessment of the floodplain (such as throughput, natural values, land use, ownership). We should prioritize areas that are essential for the safe flow of flood waves. At the same time, at least such attention should be paid to areas that do not play a decisive role in the transport of water in the river basin - such as natural heights, river ridges, belt reefs, backwaters -, as they need to take over the role of natural systems for safe drainage in the long term. 


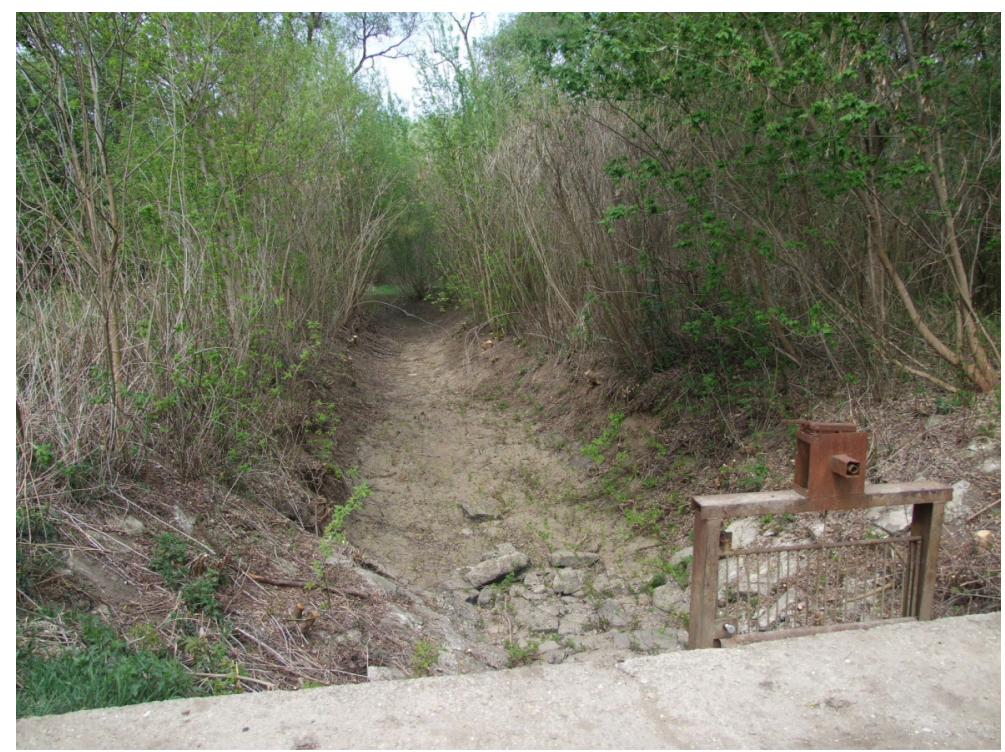

Fig. 13. The dried-out canal between the Marót-zugi-Holt-Tisza and the Mocsolya in the spring of 2019 (Photo: György Dévai, April 20, 2019)

Finally, we would like to express our conviction that a real increase in the water transport capacity of the floodplain can only be effectively achieved with the involvement and assistance of the territorial representatives of the various scientific sectors and the local population. However, due to the diversity and heterogeneity of natural systems, we do not consider it sufficient to develop general principles for this. We consider it necessary to assess and evaluate the specific conditions of the area, and to present the experience there, in a comprehensible form, not only for the professionals but also for the general public. Its effectiveness is demonstrated by the experiences and results in Germany (Vorlandmanagement Donau 2017).

\section{Acknowledgement}

Field surveys and surveys related to the River Tisza floodplain between Tiszabercel and Gávavencsellö, as well as the collection, processing and evaluation of the water level data, are carried out under KEHOP-1.1.0-15-2016-00008: "Data collection required for the preparation of VGT3, data processing, characterization of river basins, assessment of the ecological status of surface waters in the Upper Tisza, Szamos - Kraszna and Lónyay main canal subunits" belonging to the project of "Status assessments, analysis, inspections and the second review and modernization of the river basin management plans under the Water Framework Directive". We are grateful to István Láng General Director (National Directorate General for Water Management, Budapest), Lajos Illés (VIZITERV Environ Kft., Nyíregyháza), Gáspár Bodnár, Director, and Sándor Kató, Deputy Technical Director (Water Authority of Upper-Tisza Region, Nyíregyháza), for providing the working conditions. Thanks to Melinda Szabó-Márku and Roland Szolanics to editing the cross-section graphs. The research was also supported by the Higher Education Institutional Excellence Programme (NKFIH-1150-6/2019) of the Ministry of Innovation and Technology in Hungary, within the framework of the 4th thematic programme of the University of Debrecen.

\section{References}

Ács É. - Bíró T. - Berta Cs. - Duleba M. - Földi A. Grigorszky I. - Hidas A. - Knisz J. - Korponai J. L. - Trábert Zs. - Vadkerti E. - Buczkó K. (2020): Long-Term Changes of Species Composition and Functional Traits of Epiphytic Diatoms in the Szigetköz Region (Hungary) of the Danube River. - Water. 12: 776. 
Bokodi E. K. (2017): A Duna és a Tisza hidroklimatológiai jellemzése napi vízállásadatok felhasználásával. Szakdolgozat - Elte Földrajz- és Földtudományi Intézet, Meteorológiai Tanszék. Budapest. 64.

Dévai Gy. - Miskolczi M. (1997): A Tiszabercel és Gávavencsellő közötti Tisza-hullámtér ökológiai állapotfelmérése és minősítése a szitakötő-fauna (Odonata) alapján. - Studia odonatologica hungarica. 3: 63-81.

Dévai Gy. - Müller Z. (1998): A Tiszabercel és Gávavencsellő közötti Tisza-hullámtér természeti állapotának jellemzése és környezetminőségi értékelése. - Studia odonatologica hungarica. 4: 83-97.

Dévai Gy. - Végvári P. - Nagy S. - Bancsi I. (szerk.) (1999): Az ökológiai vízminősítés elmélete és gyakorlata. 1. rész. - Acta biologica debrecina, Supplementum oecologica hungarica. 10 (1), 216.

Fodor Gy. (1990): Mértékegység-lexikon. Műszaki Könyvkiadó. Budapest. 299.

Gondár K. (szerk.) (2014): A FETIVIZIG kezelésében lévő Tisza folyó nagyvízi mederkezelési terv. Tervszám: 07.NMT.03. - Meder 2014 Konzorcium, Konzorcium vezető: SMARAGDGSH Kft., Budapest.
Hein T. - Funk A. - Pletterbauer F. - Graf W. - Zsuffa I. - Haidvogl G. - Schinegger R. - Weigelhofer G. (2017): Management challanges related to long-term ecological impacts, complex stressor interactions, and different assessment approaches int he Danube River Basin. - River Research and Applications. 35 (5): 500-509.

Kiss K. - Ács É. (2002): Nature conservation oriented algal biodiversity monitoring investigations int he main arm and some dead arms of the River Tisza II. Phytoplankton. - In: IAD Limnological Reports, 34: Proceedings of the 34th Conference. Bucuresti, Románia: Editura Academiei Române. 163-171.

Pók J. (szerk.) (1996): Szabolcs vármegye (1782 - 1785). - Szabolcs-Szatmár-Bereg Megyei Önkormányzat Levéltára, Nyíregyháza. 124.

Wasserwirtschaftsamt Deggendorf (2017): Vorlandmanagement Donau. Staubing bis Vilshofen, Deggendorf. 